\title{
Further Surveys on the Antigenic Patterns of Serovars Belonging to the Semaranga Serogroup of Leptospiras
}

\author{
MARINA CINCO AND RITA DOUGAN \\ Institute of Microbiology, University of Trieste, Trieste, Italy
}

\begin{abstract}
A new leptospiral strain, Compton 699, was found to belong to serovar semaranga of the Semaranga serogroup. Antigenic analysis revealed the presence in this strain of a new main antigen which was also found in the other serovars of the same sero-group.
\end{abstract}

Serovars of the Semaranga serogroup of leptospiras were previously classified by factor analysis (1). Two subgroups were identified: one, including serovars patoc and saopaolo, is characterized by the presence of the main factor Sem. 2; the other is defined by the presence, in the serovars montevalerio and semaranga, of the main antigen Sem. 4 (1). A new strain, designated Compton 699, recently isolated from surface water (paper in press), appeared to be a member of the semaranga serovar on the basis of recommended classification schema (3). According to these recommendations, "two strains are considered to belong to different serovars if, after cross-absorption with adequate amounts of heterologous antigen, $10 \%$ or more of the homologous titer regularly remains in at least one of the two antisera after repeat tests." However, upon adsorption with "semaranga," the crossreactive titers of Compton 699 antiserum with other serovars in the semaranga group exceeded $10 \%$. To determine whether this finding reflected major antigenic differences not discernible by the suggested criteria, strain Compton 699 was further studied by the use of antigenic factor analysis. Antigenic maps of members of the Semaranga group were previously reported (1). This finding stimulated us to perform an antigenic analysis of Compton 699 on the basis of our knowledge of the antigenic maps of members of the Semaranga group.

\section{MATERIALS AND METHODS}

Bacterial strains. Strain Compton 699 was isolated from surface water in England and was sent to our laboratory for typing. The other strains were: Patoc 1, Sao Paolo, Monte Valerio, and Veldrat S 173, representing serovars patoc, saopaolo, montevalerio, and semaranga, respectively (1).

Immune sera and serological tests. The preparation of immune sera and the serological procedures used were previously described (1). Cultures used to prepare antisera were grown in albumin-Tween 80 medium and were 10 to 12 days old.

\section{RESULTS AND DISCUSSION}

Figure 1 reports the results of the absorption tests performed on Compton 699 antiserum and on the other immune sera of the Semaranga serogroup. First, it can be observed, by the absorption of Patoc 1 antiserum and Sao Paolo antiserum with strain Compton 699, that Compton 699 does not possess factor Sem. 2, but that, on the other hand, it could be supposed that it has Sem. 4. The possession of this factor by strain Compton 699 explains the titer of 1:800 against strain Veldrat S 173 in Compton 699 antiserum absorbed with Patoc 1 and Sao Paolo and the marked antigenic affinity of Compton 699 with Monte Valerio and Veldrat S 173. Furthermore, we must introduce a new main factor common to Monte Valerio, Veldrat S 173, and Patoc 1, here referred to as Sem. 7, to explain the residual titers of Monte Valerio antiserum and Veldrat S 173 antiserum absorbed with strain Compton 699. Multiple absorptions confirm the presence of this antigen. Nevertheless, it is not possible to show in Patoc 1 antiserum the presence of factor Sem. 7. Consequently we refer to it as Sem. 7 in the antigenic map of Patoc 1 (Table 1). From the absorption performed on Compton 699 antiserum, it can be concluded that minor factor Sem. 05, common to strains Sao Paolo, Monte Valerio, and Compton 699 , can be considered a main factor, which we named Sem. 6. The main serovar-specific antigenic factor of Compton 699 cannot be found, because no residual antibody remains in Compton 699 antiserum after multiple absorption with Veldrat S 173 plus strain Monte Valerio. Consequently Compton, 699 does not have its own serovar antigen. If we follow the criterion of a $10 \%$ limit, we have to assign Compton 699 to the semaranga serovar because in the reciprocal cross-absorption of Compton 699 immune antiserum and Veldrat S 173 immune antiserum, the homologous titer drops below $10 \%$. On the other hand, by factor analysis it can be seen that 


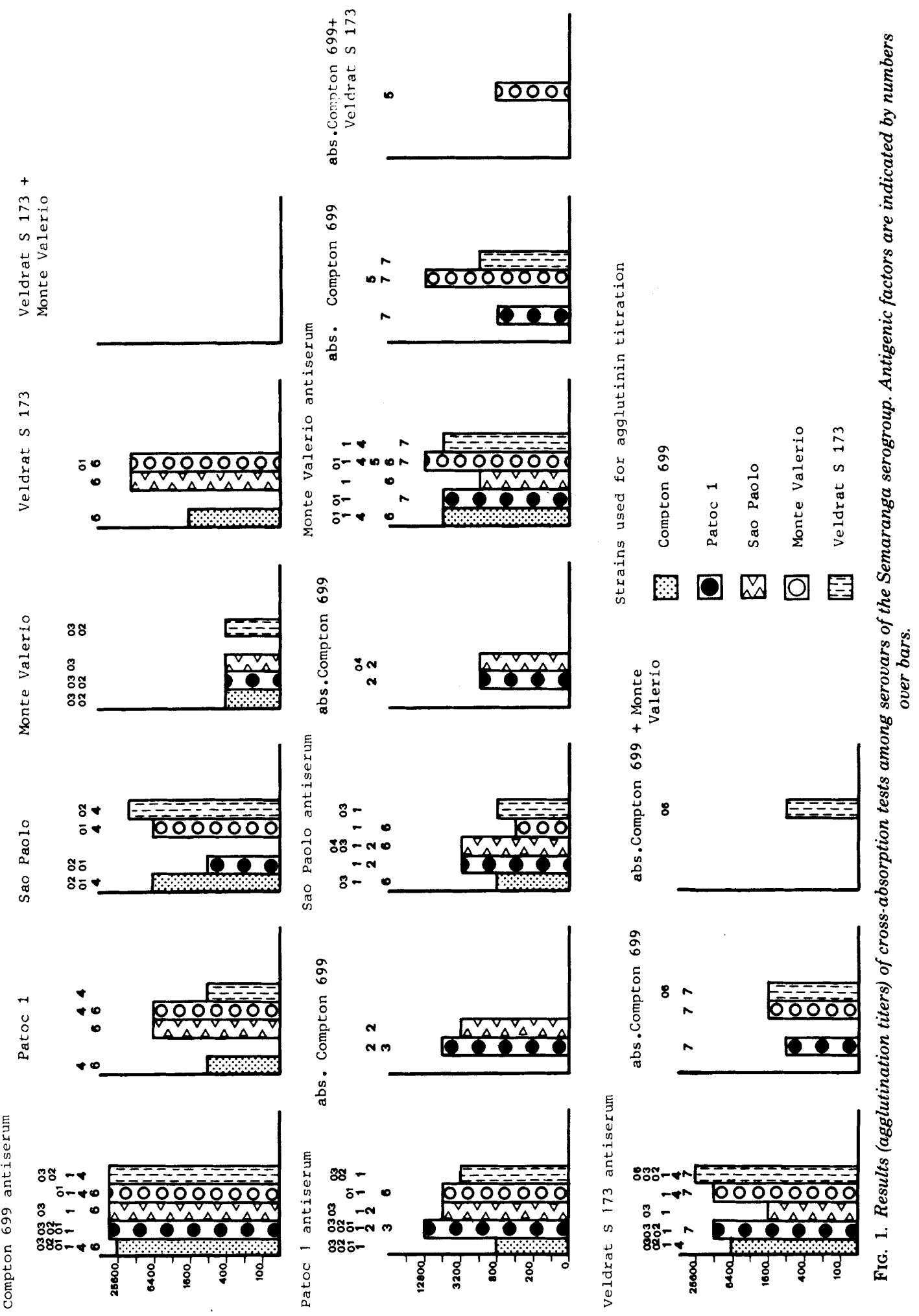


TABLE 1. Antigenic map of serovars of Semaranga serogroup of Leptospira biflexa

\begin{tabular}{|c|c|c|c|}
\hline Serovars & Reference strain & Main antigens & Minor antigens \\
\hline patoc & Patoc 1 & Sem. $1,2,3,-,-,-, 7$ & Sem. 01,02,03,-,-,- \\
\hline saopaolo & Sao Paolo & Sem. $1,2,-,-,-, 6,-$ & Sem. - $,-, 03,04,-,-$ \\
\hline montevalerio & Monte Valerio & Sem. $1,-,-, 4,5,6,7$ & Sem. 01, - , 一, - \\
\hline semaranga & Veldrat S 173 & Sem. $1,-,-, 4,-,-, 7$ & Sem. $-, 02,03,-,-, 06$ \\
\hline "semaranga" & Compton 699 & Sem. $1,-,-, 4,-, 6,-$ & Sem. $01,02,03,-,-,-$ \\
\hline
\end{tabular}

there are some differences in the compositions of the antigenic factors of each of the two strains.

This study has led to a better knowledge of the antigenic composition of the members of serogroup Semaranga: as shown in Table 1, strain Compton 699 has no antigens over and above those present in the other members of the Semaranga serogroup. Consequently there is no need to add its immune serum to those suggested for use in the initial serological screening of a new isolate (2), especially in serovar identification.

\section{REPRINT REQUESTS}

Address reprint requests to: Dr. Marina Cinco, Istituto di Microbiologia, Via A. Fleming no. 22, 34127 Trieste, Italy.

\section{LITERATURE CITED}

1. Cinco, M., and R. Dougan. 1975. Factor analysis of saprophytic serogroups Semaranga and Andamana of Leptospira biflexa. Int. J. Syst. Bacteriol. 25: 138-142.

2. Cinco, M., and I. Ivanov. 1978. Characterization of a new strain of Leptospira isolated from surface water in India. Zentralbl Bakteriol. Parasitenkd. Infektionskr. Hyg. Abt. 1 Orig. Reihe A 240:356-358.

3. World Health Organization. 1967. Ser. Rapp. Techn no. 380 . 